\title{
Reading Comprehension Question Levels in Grade X English Students' Book in Light of the Issues of Curriculum Policy in Indonesia
}

\author{
Rin Surtantini* \\ Pusat Pengembangan dan Pemberdayaan Pendidik dan Tenaga Kependidikan (PPPPTK) Seni dan Budaya Yogyakarta, Jl. Kaliurang \\ KM 12,5 Klidon, Sukoharjo, Ngaglik, Sleman, Daerah Istimewa Yogyakarta, Indonesia
}

\begin{abstract}
A B S T R A C T
This article aims at finding out the reading comprehension-question levels as constructed for some chapters of English Students' Book for Grade X published in 2017 by The Ministry of Education and Culture of Indonesia. The data were taken purposively and analyzed using Barrett's taxonomy of reading comprehension to examine the levels of comprehension questions provided in the book. While higher-order thinking skills (HOTS) in Bloom's taxonomy involve students to analyze, to evaluate, and to create, Barrett's reading comprehension levels exhibit corresponding features, namely inferential comprehension, evaluation, and appreciation. The analysis is to show the corresponse the reading comprehension questions in the book to the current issues of HOTS in the curriculum policy of Indonesia. The results demonstrate that while some of the comprehension questions (21\%) comply with the higher level of reading comprehension, the rest (nearly 80\%) show lower level of reading comprehension. In response to the implementation of the curriculum policy in Indonesia, teachers need to practice constructing higher levels of comprehension questions that considerably make students get used to think critically.
\end{abstract}

A R T I C L E I N F O

Paper type:

Research Article

Article history:

Received: 4 March 2019

Revised: 23 April 2019

Accepted: 23 April 2019

Keywords:

- Barrett's taxonomy

- Reading comprehension question

- HOTS

- Critical thinking

\section{Introduction}

Since the National Curriculum 2013 was launched in Indonesia, there have been numerous training programs designed for teachers of all subjects teaching in elementary schools, junior high schools, senior high schools and vocational high schools. The training programs have been conducted by the Ministry of Education and Culture in national and local levels, and in a number of schemes as described in Petunjuk Teknis Program Peningkatan Kompetensi Pembelajaran (Kemdikbud, 2018). Not only teachers, school principals and school supervisors have also been involved in these training programs, either as facilitators, resource persons, or participants, depending on the schemes of the programs. Along with the programs, the national curriculum policy has always been reviewed and renewed to keep on the development of global and current issues and perspectives in education. In the series of national curriculum policy, it is stated that teaching and learning processes at schools should build activities that engage students in the development of their higher-order thinking skills (HOTS).

\footnotetext{
*E-mail Addresses: rin_surtantini_widwoyo@yahoo.com.
} 
Various terms and definitions are put forward regarding the issue of HOTS. Sydoruk (2018) mentions that a lack of a formal definition of higher-order thinking contributes to the fact that no common definition existed among educational literature. The term "higher-order thinking" is used synonymously with the term "critical thinking" by some researchers with the argument that critical thinking is an essential component of a larger, broader umbrella term of higher-order thinking. Brookhart (2010) identifies three categories of definitions of higher-order thinking, namely (1) those that define higher-order thinking in terms of transfer, (2) those that define it in terms of critical thinking, and (3) those that define it in terms of problem solving. Having learnt the literature providing examples of HOTS, Sydoruk (2018) asserts that HOTS need to be built upon the essential components of critical thinking and problem solving.

In Indonesia, HOTS in the national curriculum policy are integral part of learning process and assessment. Bloom's taxonomy of educational objectives revised by Anderson et al. (2001) is used in the curriculum as the model of knowledge dimension and cognitive process dimension to design learning activities and assessment instruments. Kusuma et al. (2017) find out in their study that HOTS assessment instrument is effective to train students' thinking skills and to measure their thinking level. Jensen et al. (2014) conclude that students will obtain deep conceptual understanding of the material and better memory for the course information when they are tested throughout the semester with high-level questions. It also provides support to Bloom's proposed hierarchical nature. Abosalem (2016) in his study reveals that the tendency of schools to use the assessment methods that ask students to recall information or to do routine question will not help students in improving their higher-order thinking skills. Consequently, as Trilling \& Fadel (2009), mention there should be a wide variety of real-time formative assessments or effective methods to assess ongoing learning progress that measure content knowledge, basic and higher-order thinking skills, comprehension and understanding, and applied 21st century skills performance.

Teachers play a central role in developing students' HOTS since it is teachers who know what is best for their students by building HOTS in the ways material is presented to students and the types of activities that are given in the classroom (Sydoruk, 2018). Richland \& Begolli (2016) points out the importance of teachers in facilitating students to develop HOTS because teachers can assist students in showing multiple methods of approaching a task and can deliver useful direction to students that meets their individual learning needs. Collins (2014) asserts that teachers also need to plan assessment items that allow students to use the skills of doing analysis, evaluation, creation, logical reasoning, judgment and critical thinking, problem solving, creativity and creative thinking.

While the policy of HOTS of all subjects in the national curriculum of Indonesia takes on Bloom's revised taxonomy in terms of the cognitive level, document of Barrett's taxonomy on Cognitive and Affective Dimensions of Reading Comprehension (Byrne, n.d.) offers another way to examine the cognitive levels for reading comprehension. Barrett's taxonomy of reading comprehension consists of five major categories, namely literal comprehension, reorganization, inferential comprehension, evaluation, and appreciation. It was designed originally to assist classroom teachers in developing comprehension questions and questions of test for reading. Hence, it offers a more specific and detailed category of understanding level in terms of reading as part of English as one of the subjects in school curriculum. Javed et al. (2015) put forward Barrett's taxonomy on developing standardized reading comprehension modules to facilitate reading comprehension among Malaysian secondary schools ESL students. They focus on the construction to develop different sub-skills of reading comprehension to answer three levels of Barrett's taxonomy, namely literal, reorganization, and inferential comprehension. They believe that these three categories are similar in Bloom's taxonomy revised by Anderson et al. (2001) and in Day \& Park's (2015) taxonomy of reading comprehension. In their subsequent study on reading strategies to teach these three categories of comprehension questions, Javed et al. (2016) states that their study has the limitations of only addressing three major categories from Barrett's taxonomy of reading comprehension. This is due to the fact that only these reading levels or categories are used for teaching reading comprehension, whereas the rest, namely evaluation and appreciation in Malaysian English language syllabus are used for teaching literature. Muayanah (2014) reports that comprehension questions developed by senior high school teachers in Surabaya is still dominated by literal or the lowest level of comprehension based on Barrett's taxonomy. She argues that the questions in students' book should involve various types of comprehension questions in which there is a balance between literal and higher levels of comprehension questions. Similar findings are also reported by Gocer (2014) in his study on evaluating Turkish reading examination questions based on Barrett's taxonomy. Many questions only focus on literal comprehension level, so there are inadequate questions referring to reorganization, inferential, and evaluation level. It is recommended that teachers should give equal distribution of comprehension questions using Barrett's taxonomy. Further, he 
puts forward a suggestion to the Ministry of National Education to make a new arrangement to revise the framework of questions and acquisitions for all grades. Therefore, it is imperative that in-service training for teachers must be prepared in the pedagogical measurement-assessment field. Collamar et al. (2017) in their study on student-generated questions recommend that the school offers a seminar to teachers in all subject areas on Barrett's reading comprehension levels. By understanding the levels of reading comprehension, teachers are expected to be able to utilize student-generated questions to help them enhance their competence in asking questions as well as to check their understanding of the reading texts. Freedom of generating questions before, during, and after the reading selections trigger comprehension.

Most students' book limit reading tasks to answering a set of questions that always follow a reading text. Students may possibly can get all the answers correct since most literal comprehension questions can be answered quickly without critical thinking. How do teachers know that the students' correct answers show that they understand the reading text? Do they just match the word by chance? On the other hand, if they do not get the correct answer, is it due to the fact that they do not understand the reading text, or is it because they misunderstand the question itself? The issue of checking students' understanding also raise these questions: To what extent do the reading comprehension questions certainly help students understand? Do the questions encourage students to talk about their experiences, feelings, opinions, related to the topic of the text? Regarding this, it is critical to ask: what sort of reading comprehension questions should be asked? What is the nature of the questions? Hence, a more pragmatic approach in the evaluation of the implementation of HOTS in all learning subjects at schools is needed. Questions for reading comprehension should be in line with the issue of HOTS as the curriculum policy of Indonesia. Teachers should know what to teach in a reading class relating to the higher levels of comprehension.

The purpose of the article is to analyze the reading comprehension questions levels in Grade X English Students' Book by taking into account the Indonesian curriculum policy of developing higher-order thinking skills. Accordingly, the evaluation in this study takes some reading comprehension questions in some chapters of Bahasa Inggris SMA/MA/SMK/MAK Kelas X written by Widiati et al. (2017). The book is chosen because it was published by The Ministry of Education and Culture of Indonesia, implying that it should comply with the curriculum policy of HOTS. The evaluation employs Barrett's taxonomy of reading comprehension levels, namely (1) literal comprehension, (2) reorganization, (3) inferential comprehension, (4) evaluation, and (5) appreciation. In literal comprehension, students identify information directly stated; in reorganization, students organize or order the information a different way than it was presented; in inferential comprehension, students respond to information implied but not directly stated; in evaluation, students make judgments in light of the material; and in appreciation, students give an emotional or image-based response. The evaluation of the reading comprehension questions of the reading texts in the students' book eventually aims at examining the levels of the questions using Barrett's taxonomy, and determining whether the questions comply with the levels of Bloom's taxonomy of higher-order thinking. Inferential comprehension, evaluation, and appreciation in Barrett's taxonomy in this evaluation are considered to be equivalent with the levels of HOTS of analyzing, evaluating, and creating in Bloom's.

\section{Methods}

Data were taken purposively from the Grade X English Students' Book. The analysis focuses on the chapters in the book in which students learn text types. Reading texts are provided when students learn the text types. In most reading texts, there is a set of questions under the heading of reading comprehension questions which are taken subsequently as the data for this study. There are 122 comprehension questions being examined for the evaluation. Four text types are available in nine chapters: (1) descriptive text is available in chapters 4 and 5; (2) announcement is available in chapter 6; (3) recount is available in chapters 8, 9, 10, and 11; and (4) narrative is available in chapters 13 and 14 .

\section{Results and Discussion}

\subsection{Descriptors of the comprehension question levels}

The reading comprehension questions available in the aforementioned chapters are collected and categorized according to Barrett's taxonomy of reading comprehension levels. To categorize the level of the questions, the 
descriptors of the level are at first defined. The function of the descriptor(s) is to check in what category or what level each comprehension question belongs to. The descriptors for each comprehension level are defined in Table 1.

Table 1. Descriptors for each comprehension level

\begin{tabular}{|c|c|}
\hline $\begin{array}{l}\text { Literal comprehension (focusing on } \\
\text { ideas and information explicitly stated } \\
\text { in the text) }\end{array}$ & $\begin{array}{l}\text { - The question requires students recognition of details, main ideas, sequence, } \\
\text { comparison, cause and effect relationships, and traits by locating and identifying } \\
\text { them in the reading passage. } \\
\text { - The question requires students' recall of details, main ideas, sequence, comparison, } \\
\text { cause and effect relationships, and traits by producing them from memory. }\end{array}$ \\
\hline $\begin{array}{l}\text { Reorganization (organizing ideas or } \\
\text { information explicitly stated in the text) }\end{array}$ & $\begin{array}{l}\text { - The question asks students to classify or sort people, things, places, events, into a } \\
\text { category or a class. } \\
\text { - The question requests students to organize the reading selection to form an outline } \\
\text { using direct statements or paraphrased statements from the selection. } \\
\text { - The question asks students to condense or summarize the reading text using direct or } \\
\text { paraphrased statements from the selection. } \\
\text { The question asks students to consolidate explicit ideas or information from more } \\
\text { than one source. }\end{array}$ \\
\hline $\begin{array}{l}\text { Inferential comprehension (using ideas } \\
\text { and information in the text, their } \\
\text { intuition and personal experience as a } \\
\text { basis for prediction, estimation, } \\
\text { guesses, speculations, assumptions, } \\
\text { hypotheses) }\end{array}$ & $\begin{array}{l}\text { - The questions requires students to conjecture supporting details, main ideas, } \\
\text { sequence, comparisons, cause and effect relationships, character traits of clues } \\
\text { presented in the text. } \\
\text { The questions asks students to predict outcome by reading an initial portion of the } \\
\text { reading text. } \\
\text { The questions needs students to infer literal meanings from the author's figurative } \\
\text { use of language. }\end{array}$ \\
\hline $\begin{array}{l}\text { Evaluation (dealing with evaluative } \\
\text { thinking and judgment and focusing on } \\
\text { qualities of accuracy, acceptability, } \\
\text { desirability, worth, or probability of } \\
\text { occurrence). }\end{array}$ & $\begin{array}{l}\text { - The question requires students' reponses to make evaluative judgment of reality, } \\
\text { fantasy, fact, opinion, adequacy, validity, appropriateness, worth, desirability, } \\
\text { acceptability. }\end{array}$ \\
\hline $\begin{array}{l}\text { Appreciation (dealing with emotional } \\
\text { and aesthetic impact of the text) }\end{array}$ & $\begin{array}{l}\text { - The question requires students to verbalize their feelings about the content of the } \\
\text { reading text in terms if interest, excitement, boredom, fear, hate, amusement, etc. } \\
\text { - The question asks students to demonstrate their sensitivity to, sympathy for, and } \\
\text { empathy with characters, happenings, and ideas portrayed by the author. } \\
\text { - The question asks the reactions to the author's use of language such as denotations } \\
\text { and connotations of words. }\end{array}$ \\
\hline
\end{tabular}

\subsection{Levels of reading comprehension questions}

Using the defined descriptors, 122 questions are examined into the reading comprehension levels. Table 2 presents the result of the categories of the questions. A careful look at the reading text is also done to help put the question into the appropriate category.

Table 2. Reading comprehension levels of questions in English Students' Book Grade X

\begin{tabular}{llllllll}
\hline \multirow{2}{*}{ Chapter } & \multirow{2}{*}{ Text Type } & \multicolumn{2}{l}{ Reading comprehension levels } & & Number of \\
\cline { 3 - 6 } & Literal & Reorganization & Inferential & Evaluation & Appreciation & questions \\
\hline 4 & Descriptive & 11 & 1 & 5 & 4 & 0 & 1 \\
5 & Descriptive & 11 & 0 & 0 & 0 & 1 & 12 \\
6 & Announcement & 14 & 0 & 1 & 0 & 0 & 15 \\
8 & Recount & 11 & 0 & 0 & 2 & 0 & 13 \\
9 & Recount & 8 & 0 & 1 & 2 & 0 & 11 \\
10 & Recount & 11 & 0 & 1 & 0 & 0 & 12 \\
11 & Recount & 15 & 0 & 0 & 0 & 1 & 16 \\
13 & Narrative & 9 & 0 & 0 & 1 & 0 & 10 \\
14 & Narrative & 7 & 0 & 2 & 0 & 1 & 10 \\
\hline \multicolumn{2}{l}{ Number of questions } & 97 & 1 & 11 & 9 & 4 & 122 \\
\hline
\end{tabular}

Table 2 shows that the distribution of the comprehension questions in the book does not spread evenly. Literal comprehension dominates the level of reading comprehension (nearly 80\%) of the construction of all 
reading comprehension questions in the book. The levels of comprehension that involve students' critical thinking --inferential, evaluation, and appreciation in Barrett's, or analyzing, evaluating, and creating in Bloom's-- show less portion of the whole question construction (only $21 \%$ ).

\subsection{Literal comprehension questions}

There are 97 reading comprehension questions constructed in the level of literal comprehension based on two descriptors defined. Table 3 a shows some of the examples of the first descriptor that require students' recognition of details, main ideas, sequence, comparison, cause and effect relationships, and traits by locating and identifying them in the reading passage.

Table 3a. Examples of literal comprehension questions (recognition) in English Students’ Book Grade X

\begin{tabular}{|c|c|c|c|}
\hline No. & Questions & Features of Descriptor & Units \\
\hline 1. & How can people reach Camp Leakey? & Detail & Chapter 4 \\
\hline 2. & How is the park different from the parks in cities? & Comparison & Chapter 4 \\
\hline 3. & Who is the announcement for? & Detail & Chapter 6 \\
\hline 4. & When and where was the meet-and-greet event? & Detail & Chapter 8 \\
\hline 5. & When did the battle take place? & Detail & Chapter 9 \\
\hline 6. & What happened to Habibie in $1962 ?$ & Main idea & Chapter 10 \\
\hline 7. & Why did the Dutch put her into exile in Sumedang? & Cause and effect relationship & Chapter 11 \\
\hline 8. & $\begin{array}{l}\text { Give an example that Malin Kundang was a healthy, dilligent, and strong } \\
\text { boy! }\end{array}$ & Traits & Chapter 13 \\
\hline
\end{tabular}

The second descriptor requires students' recall of details, main ideas, sequence, comparison, cause and effect relationships, and traits by producing them from memory. The following examples in Table $3 \mathrm{~b}$ meet this descriptor.

Table 3b. Examples of literal comprehension questions (recall) in English Students' Book Grade X

\begin{tabular}{llll}
\hline No. & Questions & Features of Descriptor & Units \\
\hline 9. & Find out the similarities between text 1 (Tanjung Puting National Park\} and & Comparison & Chapter 4 \\
& text 2 (Taj Mahal). & Cause and effect relationship & Chapter 4 \\
10. & Why did the king construct Taj Mahal? & Chapter 5 \\
11. & Mention the three waterfalls that form the Niagara Falls. & Detail & Chapter 6 \\
12. & What did Faith \& D Entertainment write in the last paragraph? & Main idea & Chapter 9 \\
13. & Draw a diagram that shows chronologically the events that led to the battle. & Sequence & \\
\hline
\end{tabular}

As the typical characteristic of literal comprehension question is focusing on ideas and information explicitly stated in the text, the questions are in fact easy to construct and therefore can be found in all chapters conceivably. With this feature, students can quickly get the answers right since they just can obtain the answers in the reading text itself. As in example (10), the question word "Why" does not require students to infer and state the reason underlying their inferences since the answer is obviously located and identified in the reading passage. The majority of the literal comprehension questions found in the book asks about details and main idea. Sequence, comparison, cause and effect relationships and traits are rarely found.

\subsection{Reorganization questions}

It is peculiar that there is only one question dealing with reorganization: question that asks students to classify, outline, synthesize or summarize. In fact, the questions for this type of comprehension level is not hard to construct, and the reading passages which belong to four text types available in the book also provide contents enabling the construction of this question type. Unfortunately, classifying, summarizing and synthesizing are not found. The only question found for this level is outlining, as shown in Table 4.

Table 4. Example of reorganization question in English Students' Book Grade X

\begin{tabular}{llll}
\hline No. & Questions & Features of Descriptor & Units \\
\hline 14. & How does the writer organize his idea? & Outlining & Chapter 4 \\
\hline
\end{tabular}


Through this question, students are asked to divide the story into parts that show the outline of the ideas of the reading text.

\subsection{Inferential questions}

There are 11 reading comprehension questions constructed in the inferential level based on three descriptors defined, namely inferring, predicting outcome, and interpreting figurative language. Questions that ask students to predict outcome is not found. Table 5 shows some of the questions in inferential level.

Table 5. Examples of inferential questions in English Students’ Book Grade X

\begin{tabular}{|c|c|c|c|}
\hline No. & Questions & Features of Descriptor & Units \\
\hline 15. & $\begin{array}{l}\text { What does the word ex-captive tell you about the orangutans in Camp } \\
\text { Leakey, which is a rehabilitation site for orangutans? }\end{array}$ & Inferring main ideas & Chapter 4 \\
\hline 16. & What does the phrase 'the crown of the palace' imply? & $\begin{array}{l}\text { Interpreting figurative } \\
\text { language }\end{array}$ & Chapter 4 \\
\hline 17. & $\begin{array}{l}\text { What do you think about the Indonesian military power compared to that of } \\
\text { the British army at that time? }\end{array}$ & Inferring comparisons & Chapter 9 \\
\hline 18. & Had Habibie met Ainun before meeting her in $1962 ?$ & Inferring supporting details & Chapter 10 \\
\hline 19. & $\begin{array}{l}\text { Why did Strong Wind decide to have the chief's youngest daughter as his } \\
\text { wife? }\end{array}$ & $\begin{array}{l}\text { Inferring cause and effect } \\
\text { relationship }\end{array}$ & Chapter 14 \\
\hline
\end{tabular}

Inferential questions are challenging to construct since they need much more time to do; besides, the students are also required to work out the implication, conjecture, as well as reasoning behind their inferences. In other words, the questions are challenging both for the person who constructs the questions and students who need to answer the questions.

\subsection{Evaluation questions}

There are 9 questions constructed in the evaluation level based on one descriptor defined. The examples of the evaluation questions are shown in Table 6.

Table 6. Examples of evaluation questions in English Students' Book Grade X

\begin{tabular}{llll}
\hline No. & Questions & Features of Descriptor & Units \\
\hline 20. & When do you think is the best time to see Taj Mahal? Why do you think so? & Opinion & Chapter 4 \\
21. & How important is the research by Dr. Birute Galdikas? & Chapter 4 \\
22. & Why do you think people like Afgan? & Worth & Appropriateness \\
23. & Did the Indonesian lose or win the battle? Why do you think so? & Chapter 9 \\
24. & What is the moral of the story? & Fact & Chapter 13 \\
\hline
\end{tabular}

The descriptor of the evaluation questions shows that the questions encourage students to make evaluative judgment by comparing ideas presented in the reading text using their own criteria such as their experiences, values, knowledge, or others' criteria they obtained from teacher, written references, etc. Evaluative judgment is obtained from students' evaluative thinking to the case being asked. Based on the pattern of the descriptor, this type of question is actually not too complicated to construct. However, it is worth asking why in the book there are not many questions with this level constructed for students' development of critical thinking.

\subsection{Appreciation questions}

There are four questions belong to the level of appreciation found in the reading comprehension questions in the book, as can be seen in Table 7. 
Table 7. Examples of appreciation questions in English Students’ Book Grade X

\begin{tabular}{llll}
\hline No. & Questions & Features of Descriptor & Units \\
\hline 25. & What impression did you get after reading the description? & $\begin{array}{l}\text { Emotional response to the } \\
\text { content }\end{array}$ & Chapter 4 \\
26. & $\begin{array}{l}\text { If you had an opportunity to visit Niagara Falls, which attraction would you } \\
\text { visit first? Why? }\end{array}$ & Sensitivity to ideas & Chapter 5 \\
27. $\quad \begin{array}{l}\text { Had you lived close to Cut Nyak Dhien, what would you have done to } \\
\text { support her efforts in fighting against the Dutch colonialization? }\end{array}$ & $\begin{array}{l}\text { Sympathy for and empathy } \\
\text { with the character }\end{array}$ & Chapter 11 \\
28. $\quad$ If you were in the story, which role would you play? Why? & $\begin{array}{l}\text { Sympathy for and empathy } \\
\text { with the character }\end{array}$ & Chapter 14 \\
\hline
\end{tabular}

The level of appreciation questions is rarely found in the reading comprehension questions in the book since the feature of this question is related to author's use of language and imagery. Most of the reading texts provided -descriptive, narrative, recount, and announcement-- do not expose the author's craftsmanship in terms of the semantic dimension of the text, namely, connotations of words. Besides, most of the texts also do not highlight the author's artistic ability to pain word pictures which cause the students to use their senses (such as visualizing, hearing, or feeling), since they are not literary works.

\subsection{HOTS and reading comprehension questions}

Considering that the national curriculum policy demands the implementation of learning activities which encourage students to get used to think critically, it is essential to design comprehension questions which put forward HOTS. Table of specifications of reading questions is then used to construct the questions with the reading sub-skills, question levels, question formats, and number of items. By doing this, the reading comprehension levels can be spread in an even way. What is more, the emphasis on higher levels of reading comprehension can be determined. Having read all the questions under the heading of reading comprehension, the construction of reading questions in the English Students' Book Grade X can be seen in Table 8.

Table 8. Specification of reading comprehension questions in English Students' Book Grade X

\begin{tabular}{|c|c|c|c|}
\hline Reading sub-skills & Question levels & Question formats & $\begin{array}{l}\text { Number of } \\
\text { items }\end{array}$ \\
\hline $\begin{array}{l}\text { Identify main facts, details, sequence, events, comparison, } \\
\text { cause and effect relationships, and traits in the reading text }\end{array}$ & Literal comprehension & Open-ended question & 97 \\
\hline $\begin{array}{l}\text { Organize ideas or information in the reading text into an } \\
\text { outline }\end{array}$ & Reorganization & Open-ended question & 1 \\
\hline $\begin{array}{l}\text { Drawing inferences of main ideas, comparison, supporting } \\
\text { details, cause and effect relationship from the context }\end{array}$ & Inferential comprehension & Open-ended question & 11 \\
\hline $\begin{array}{l}\text { Making evaluative judgment from evaluative thinking on } \\
\text { ideas provided in the reading text }\end{array}$ & Evaluation & Open-ended question & 9 \\
\hline Expressing emotional response to the reading text & Appreciation & Open-ended question & 4 \\
\hline
\end{tabular}

Table 8 demonstrates that reading sub-skills in the question construction vary to comply with five levels of Barrett's reading taxonomy. However, question formats do not vary whatsoever since they are all designed as open-ended questions. Furthermore, number of items representing each question levels are not in balance since lower level of questions, namely literal comprehension, dominate the question construction. Hence, the construction of reading comprehension questions in English Students' book for Grade X only correspond partially with the endorsed national curriculum.

\section{Conclusion and Suggestion}

Reading comprehension levels are supposed to come together with reading sub-skills to construct a set of questions in the teaching of reading. Both reading comprehension levels and reading sub-skills are crucial in a reading lesson. Therefore, it is necessary beforehand to design table of specifications of reading questions comprising a range of reading sub-skills, reading levels, questions formats, and number of items. To do this, teachers can use Barrett's taxonomy to help them in guiding questioning and in developing comprehension questions or test questions for the reading lessons. 
Taking into account the issue of developing HOTS in the national curriculum, it is recommended that teachers should practice and improve the design or construction of reading comprehension question levels in English Students' Book Grade X. The number of literal questions should be reduced, while the number of questions belonging to inferential, evaluation, and appreciation levels should be added up to conform to the endorsed policy. Regarding this, Barrett's taxonomy helps a lot in creating questions depending on each level category. Variations of questioning or making questions in the forms of examples and patterns based on each comprehension level are provided in Barrett's. In a more general context, it is also essential that in pragmatic level, the issue of developing HOTS in national curriculum policy should not remain theoretical and not downto-earth. HOTS in theoretical and conceptual perspective in the policy should embrace or be decoded into a range of more practical learning activities, learning modules, students' book, assessment instruments, and teaching and learning aids. Hence, it is imperative that all in-service training programs for teachers of all subjects must include these hands-on materials, one of which is developing HOTS measurement-assessment instruments.

\section{References}

Abosalem, Y. (2016). Assessment techniques and students' higher-order thinking skills. International Journal of Secondary Education, IV(1), 1-11. doi:10.11648/j.ijsedu.20160401.11

Anderson, L.W., Krathwohl, D.R., Airasian, P.W., et al. (Eds.). (2001). A taxonomy for learning, teaching, and assessing: A revision of Bloom's Taxonomy of Educational Objectives. New York: Longman.

Brookhart, S. M. (2010). How to Assess Higher-Order Thinking Skills in Your Classroom. Retrieved from http://www.ascd.org/publications/books/109111/chapters/Introduction.aspx

Byrne, W. J. (n.d.). Cognitive and Affective Dimensions of Reading Comprehension. Retrieved from Curriculum Concepts for Parents and Adults: http://joebyrne.net/curriculum/barrett.pdf

Collamar, R., Karaan, A. M., \& Palma, M. S. (2017). Questions students ask as indices of their comprehension. Journal on Teacher Education, XI(1), 109-140. Retrieved from http://po.pnuresearchportal.org/ ejournal/index.php/normallights/article/view/378

Collins, R. (2014). Skills for the 21st century: teaching higher-order thinking. Curriculum and Leadership Journal, XII(14). Retrieved from https://vhsteams.files.wordpress.com/2015/10/curriculumleadership-journal-skills-for-the-21st-century-teaching-higher-order-thinking.pdf

Day, R. R., \& Park, J.-s. (2015). Developing reading comprehension questions. Reading in a Foreign Language, XVII(1), 60-73. Retrieved from http://nflrc.hawaii.edu/rfl

Direktorat Jenderal Guru dan Tenaga Kependidikan. (2018). Petunjuk Teknis Program Peningkatan Kompetensi Pembelajaran Berbasis Zonasi. Jakarta: Kementerian Pendidikan dan Kebudayaan.

Gocer, A. (2014). The assessment of Turkish written examination questions based on text in accordance with the Barrett's taxonomy. International Journal of Languages' Education and Teaching 3, 1-16. Retrieved from https://eric.ed.gov/?id=ED557158

Javed, M., Eng, L. S., \& Mohamed, A. R. (2015). Developing reading comprehension modules to facilitate reading comprehension among Malaysian Secondary School ESL students. International Journal of Instruction, VIII(2), 139-154. Retrieved from www.e-iji.net

Javed, M., Eng, L. S., Mohamed, A. R., \& Ismail, S. A. (2016). Identifying reading strategies to teach literal, reorganization and inferential comprehension questions to ESL students. The Journal of Asia TEFL, XIII(III), 204-220. doi:10.18823/asiatefl.2016.13.3.3.204

Jensen, J., McDaniel, M. A., Woodard, S. M., \& Kummer, I. A. (2014). ). Teaching to the Test... or Testing to Teach: Exams Requiring Higher Order Thinking Skills Encourage Greater Conceptual Understanding. Educational Psychology Review, XXVI(2), 307-329. doi:10.1 007/s 1 0648-0 1 3-9248-9

Kusuma, M. D., Rosidin, U., Abdurrahman, \& Suyatna, A. (2017). The development of higher order thinking skills (HOTS) instrument assessment in Physics study. IOSR Journal of Research \& Method in Education, VII(1), 26-32. Retrieved from http://www.iosrjournals.org

Muayanah, M. (2014). Reading comprehension questions developed by English teachers of senior High Schools in Surabaya. Jurnal Sosial Humaniora, VII(1), 20-44. Retrieved from http://iptek.its.ac.id/index.php/ jsh/article/view/594

Richland, L.E., \& Begolli, K.N. (2016). Analogy and Higher Order Thinking: Learning Mathematics as an Example. Policy Insights from the Behavioral and Brain Sciences 3(2), 160-168. doi: $10.1177 / 2372732216629795$ 
Sydoruk, P. D. (2018). An Analysis of the Higher Order Thinking Requirements of a Grade 8 Online-Based English Language Arts Skills Program. Seton Hall University Dissertations and Theses (ETDs). Retrieved from https://scholarship.shu.edu/dissertations/2495

Trilling, B., \& Fade, C. (2009). 21st Century Skills: Learning for Life in Our Times. San Fransisco: JoseyBass.

Widiati, U., Rohmah, Z. \& Furaidah (2017). Bahasa Inggris SMA/MA/SMK/MAK Kelas X. Edisi Revisi. Jakarta: Kementerian Pendidikan dan Kebudayaan. 